\title{
Reproductive activity alterations on the Biomphalaria glabrata exposed to Euphorbia splendens var. hislopii latex
}

\author{
Clélia Christina Mello-Silva/ ${ }^{+}$, Mônica Magno Vilar , José Clecildo Barreto Bezerra*, \\ Maurício Carvalho de Vasconcellos**, Jairo Pinheiro***, \\ Maria de Lurdes de A Rodrigues****
}

\begin{abstract}
Laboratório de Esquistossomose Experimental ** Laboratório de Avaliação e Promoção da Saúde Ambiental, Instituto Oswaldo Cruz-Fiocruz, Av. Brasil 4365, 21045-900, Rio de Janeiro, RJ, Brasil *Instituto de Patologia Tropical e Saúde Pública, Universidade Federal de Goiás, Goiânia, GO, Brasil ***Departamento de Ciências Fisiológicas, Instituto de Biologia ****Programa de PósGraduação em Ciências Veterinárias, UFRRJ, Seropédica, RJ, Brasil
\end{abstract}

The reproductive activity of Biomphalaria glabrata exposed to Euphorbia splendens var. hislopii latex was evaluated. Parameters related to fecundity and fertility were observed. The snails were exposed to the $L D_{50}$ $(1 \mathrm{mg} / \mathrm{l})$ of crude latex. At the first week post exposure (p.e.), the egg laying was reduced. After the fourth week p.e., an increase of the number of eggs/snail occurred. The results showed a marked reduction in the hatching of the snails, revealing an interference of latex exposure with the reproductive process of $\mathrm{B}$. glabrata of E. splendens var. hislopii. The $L D_{50}$ of the latex may be used as an alternative method to control the size of the populations of $\mathrm{B}$. glabrata in field.

Key words: Biomphalaria glabrata - plant moluscicide - reproductive activity alteration - snail population control

The reproductive potential of Biomphalaria glabrata, the main intermediate host of Schistosoma mansoni in Brazil, is straightly related to environmental conditions (Magalhães \& Lucca 1971, Kawazoe 1977).

The physiological stress factors, as temperature variations (Pimentel-Souza et al. 1990), lightness (Barbosa et al. 1987), starvation (Livingstone \& Zwaan 1983), and parasitism by larval trematodes (Looker \& Etges 1979, Sullivan et al. 1985, Cooper et al. 1994, Cousin et al. 1995) have been pointed as able to influence the reproductive biology of the snails.

There are few studies on the interference of plants that exhibit moluscicide action with the reproductive activity of the snails, intermediate host of helminthes. The reproductive capacity of $B$. alexandrina is reduced when it was exposed to Allium sativum, A. cepa, and Atriplex halimus (Mantawy 2001, Tanatawy 2002).

Many molluscicide have been used to schistosomiasis control, and one of the most promising and widely studied in Brazil, is the crude latex of Euphorbia splendens var. hislopii. The latex obtained from this plant, under laboratory and field conditions, showed that it attends to queries needed to be used as a natural molluscicide (Schall et al. 2001, Vasconcelllos \& Amorim 2003 a,b).

The lethal effects on the embryos in the egg masses were obtained using elevated concentrations of the latex (870 a $1500 \mathrm{mg} / \mathrm{l})$ (Schall et al. 1998), but, until the moment, there were no studies focusing the latex effects on the reproductive biology of $B$. glabrata.

${ }^{+}$Corresponding author: clelia@ioc.fiocruz.br

Received 12 December 2006

Accepted 13 August 2007
The objective of this study was evaluating the influence of sub lethal dose $\left(\mathrm{LD}_{50}\right)$ of latex of E. splendens var. hislopii on reproductive parameters of B. glabrata.

\section{MATERIALS AND METHODS}

Collection of E. splendens var. hislopii latex - Samples of E. splendens var. hislopii latex were collected in the autumn from plants cultivated in plots near Departamento de Biologia, Instituto Oswaldo Cruz-Fiocruz, Rio de Janeiro, RJ, Brazil. The latex was collected as described by Vasconcellos and Amorim (2003a), on the same day of tests conduction.

Rearing of B. glabrata in the laboratory - Specimens of B. glabrata (Belo Horizonte, BH lineage) were reared at the Laboratório de Esquistossomose Experimental, Instituto Oswaldo Cruz-Fiocruz, RJ, Brazil. The snails were placed in 301 polyethylene aquaria, with dechlorinated water. The average water temperature was $28 \pm$ $1{ }^{\circ} \mathrm{C}$ and relative humidity varied from 70 to $78 \%$ throughout the experiment.

Three times a week the aquaria were cleaned and the snails were fed ad libitum with lettuce leaves (Lactuca sativa L.). All the specimens of B. glabrata used in the experiments had shell diameters between $8-10 \mathrm{~mm}$ and exhibit ovipository activity.

Determination of sublethal concentrations of latex of E. splendens var. hislopii - The determination of $\mathrm{LD}_{50}$ were made according to Vasconcellos and Amorim (2003a), in accordance to WHO recommendations (WHO 1983) and Mott (1987), being obtained $\mathrm{LD}_{50}$ value equal to $1 \mathrm{mg} / \mathrm{l}$ (Mello-Silva 2005, Mello-Silva et al. 2006).

Reproductive biology of B. glabrata exposed to $L D_{50}$ of E. splendens var. hislopii latex - Sixty specimens of B. glabrata were exposed to $\mathrm{LD}_{50}$ of $E$. splendens var. hislopii latex by $24 \mathrm{~h}$ and, after this time, they were 
washed in dechlorinated tap water and 30 of these animals were maintained in three aquaria, with 10 snails each. Thirty snails were used as control group (unexposed).

The snails were weekly observed until the fifth week p.e. the parameters related to the reproductive biology analyzed were: number of live snails, number of egg masses laid by snail, number of eggs/egg mass, number of eggs laid/snail, and number of hatched snails/week.

Statistical analysis - The results were expressed as mean \pm standard deviations and subjected to a variance analysis test (ANOVA), to the Tukey-Kramer test, and to Student's t-test for unpaired data for comparing the means $(\alpha=5 \%)$. Linear regression tests was used to verify the significance of the relation between the parameters observed and the time post exposed (p.e), except to the data on survival to which the Chi-Square test was used (Graph Pad Prism, v.3.00, and GraphPad InStat, v. 3.06, GraphPad Software Inc.).

\section{RESULTS}

The number of survivorship of unexposed snails was significantly higher than those exposed to E. splendens latex (Table I), with a percentual survival of $60 \%, 10$ snails died in the initial $24 \mathrm{~h}$ (p.e), while to unexposed snails the survival was equal to $93.3 \%$ (Chi-Square $=$ 7.54; $P<0.01)$. This parameter was negatively related to the time p.e. in both groups (exposed and unexposed), but the survival of the exposed snails was always lower than the observed to the unexposed snails.

The latex exposition caused a reduction of $25.01 \%$ in the total number of the egg masses of B. glabrata (Table I). When the number of eggs masses/snail was compared between the both groups (exposed and unexposed), a reduction of $25.14 \%$ was observed to exposed snails in relation the unexposed animals (Table II). The linear regression showed a positive relation between the number of egg masses/snail and the time post exposure, in weeks (control: $y=1.67+0.75 x$; exposed: $y=0.30$ $+0.92 \mathrm{x})$, which was marked significant to the exposed snails (Table II).

The mean number of eggs laid/snail was reduced in $17.3 \%$ when B. glabrata was exposed to E. splendens var. hislopii latex (Table II) in relation to control group.
But, when these data were analyzed weekly, it was possible verify that this reduction occurred until the third week p.e. Onwards, the number of eggs laid/snail to this group was higher than that observed to unexposed $B$. glabrata. Similar response was observed when the number of eggs/egg mass laid by B. glabrata, being observed an increase of $13.04 \%$ in relation to control group at the end of the period analyzed, but this difference was not significant. A reduction was also observed to the number of eggs/egg mass until the third week p.e. and an increase occurred from the fourth week onwards. As the number of eggs/egg mass (control: $y=317+2.2 x$; exposed: $\mathrm{y}=3.16+2.67 \mathrm{x})$, as the number of eggs laid/ snail (control: $\mathrm{y}=24.6+6.4 \mathrm{x}$; exposed: $\mathrm{y}=-0.20+$ $13.08 \mathrm{x}$ ) presented a positive relation with the time after exposition to latex.

The mean number of hatched snails came from eggs laid by $B$. glabrata unexposed to E. splendens var. hislopii latex was significantly different and higher than that observed to the exposed snails (Table II). The linear regression analysis revealed a positive relation between these values and the period of observation to both groups $(y=7.86+9.5 x)$, but this relation was strongest to the snails unexposed to E. splendens var. hislopii latex $(\mathrm{y}=$ $57.49+18.25 x)$. The statistic analysis for parameters should be observed by different letters (Table II).

\section{DISCUSSION}

The use of sub lethal dose $\left(\mathrm{LD}_{50}\right)$ of the crude $E$. splendens var. hislopii latex, in the present study, caused a marked mortality of $60 \%$ of B. glabrata at the first 24 $\mathrm{h}$ post exposure. This mortality percentual was observed after exposure to E. splendens latex in Lymnaea columella (intermediate host of Fasciola hepatica) by Vasconcellos and Amorim (2003b).

Studies about duration of the molluscide effects of the aqueous solution of E. splendens var. hislopii latex on freshwater snails showed that the moluscicide effect of latex was lost due sunlight exposition (Schall et al. 1992). Vasconcellos and Amorim (2003a) showed that the latex is photosensible and biodegradable.

In this study, an important statement was that even after E. splendens var. hislopii latex looses it mollusci-

TABLE I

Total values of the reproductive biology of Biomphalaria glabrata exposed (E) and unexposed (C) to Euphorbia splendens var. hislopii latex, after $24 \mathrm{~h}$ of exposition and observed through five weeks

\begin{tabular}{|c|c|c|c|c|c|c|c|c|}
\hline \multirow[b]{2}{*}{ Time } & \multicolumn{2}{|c|}{ Total snails surviving } & \multicolumn{2}{|c|}{ Egg masses } & \multicolumn{2}{|c|}{ Eggs } & \multicolumn{2}{|c|}{ Snails hatched } \\
\hline & $\mathrm{C}$ & $\mathrm{E}$ & $\mathrm{C}$ & $\mathrm{E}$ & $\mathrm{C}$ & $\mathrm{E}$ & $\mathrm{C}$ & $\mathrm{E}$ \\
\hline Day 0 & 30 & 30 & - & - & - & - & - & - \\
\hline 1 st day & 30 & 20 & 5 & - & 31 & - & 20 & - \\
\hline 1 st week & 29 & 19 & 117 & 16 & 974 & 194 & 517 & 100 \\
\hline 2 nd week & 28 & 18 & 115 & 65 & 1216 & 541 & 459 & 133 \\
\hline 3 rd week & 28 & 18 & 128 & 66 & 1470 & 695 & 118 & 77 \\
\hline 4 th week & 28 & 18 & 141 & 77 & 1603 & 1116 & 195 & 166 \\
\hline 5 th week & 28 & 18 & 115 & 74 & 1457 & 1040 & 435 & 155 \\
\hline Total & - & - & 621 & 298 & 6751 & 3586 & 1744 & 631 \\
\hline
\end{tabular}




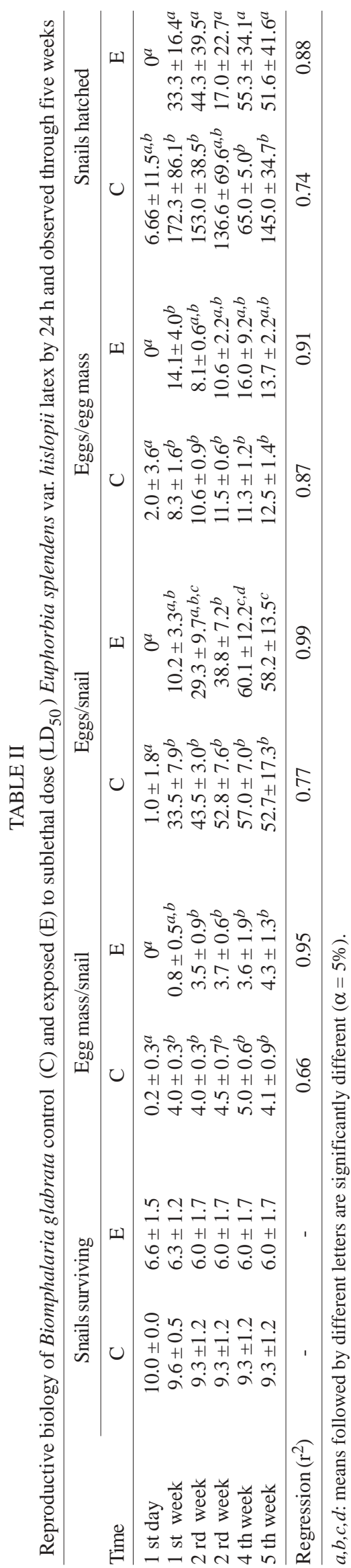

cide activity, at the concentration used $\left(\mathrm{LD}_{50}\right)$, caused interference on the reproductive function of the $B$. glabrata. This interference had direct relation with the alterations in glucose level of the hemolymph, with previous observations in snails exposed to latex (Mello-Silva 2005, Mello-Silva et al. 2006). The regulation of glicemia in snails was observed by Thompson and Lee (1986) and in the present study, probably occurred a conversion of galactogen in glycogen, which was redirected from the reproduction to nutrition, to maintain the glucose levels to survival during the time of experiment.

In the present study, the decreasing of the number of egg masses associated to the increase in the number of eggs laid/snail and the number of eggs/egg mass, clearly reflect an attempt to compensate the reproductive losses occurred early, before the fourth week, this fact is commonly observed in physiologically stressed snails. The snails presented a minor energetic waste in their process of reproduction, laying a higher number of eggs in each egg mass, resulting in an increased efficiency of this process and a lower spent of energy, similar phenomenon was observed in $S$. mansoni infected snails (Minchella 1985), with a major number of eggs produced in the beginning of the infection as a strategy to compensate the reduction that will occur at the following phases of the larval intramolluscan development of the parasite. The reduction on fecundity associated to the intermediate and final phases of the S. mansoni larval development, coinciding with the depletion of the energy stores, as the glycogen deposits of the digestive gland, verifying that the eggs production decreases after 20 days post infection (Looker \& Etges 1979, Crews \& Yoshino 1989, 1991).

The E. splendens latex, as a moluscicide substance, has been shown satisfactory results to the control of the hatched snails population. So, when this substance is tested against egg masses, Schall et al. (1998) observed that a higher concentration was needed, $1500 \mathrm{ppm}$, to kill the embryos. In the present study, the sublethal dose, $1 \mathrm{mg} / \mathrm{l}$, altered significantly the fertility of the adult snails, acting indirectly on the population control.

Many natural products have been used in high concentrations, interfering with different reproductive parameters (Schall et al. 1992, 1998, Souza et al. 1992, Mantawy 2001, Bacchetta et al. 2002, Tantawy 2002). But, by the first time it was showed that the concentration of E. splendens var. hislopii latex $(1 \mathrm{mg} / \mathrm{l})$ used in this study, must be efficient to the control of B. glabrata populations even after the residual time p.e.

The control of the population size of B. glabrata in field has been used by the competitor snails, with relevance for Melanoides tuberculatus (Giovanelli et al. 2005). In the present study, the control did not eliminate the snail of the aquatic environments, but may be used as an alternative method to control the size of the populations of $B$. glabrata in field by interfere with its reproductive process and will be utilized to transmission control for schistosomiasis according stated by King et al. (2006). 


\section{REFERENCES}

Bacchetta R, Mantecca P, Vailati G 2002. Oocyte degeneration and altered ovipository activity induced by Paraquat in the freshwater snail Physa fontinalis (Gastropoda: Pulmonata). J Moll Stud 68: 181-186.

Barbosa NDC, Pimentel-Souza FC Sampaio IBM 1987. The effect of scasonal, temperature and experimental illumination on reproductive rate in the snail Biomphalaria glabrata. Brazilian J Med Biol Res 20: 685-696.

Cooper LA, Richards CS, Lewis FA, Minchella, DJ 1994. Schistosoma mansoni: relation ship between low fecundity and reduced susaptibility to parasite infection in the snail Biomphalaria glabrata. Exp Parasitol 79: 21-28.

Cousin C, Ofori K, Acholonou S, Miller A, Richards C, Lewis F, Knight M 1995. Schistosoma mansoni: changes in the albumen gland of Biomphalaria glabrata snails selected for nonsusceptibility to the parasite. J Parasitol 81: 905-911.

Crews AE, Yoshino TP 1989. Schistosoma mansoni: effect of infection on reproduction and gonodal growth in Biomphalaria glabrata. Exp Parasitol 68: 326-334.

Crews AE Yoshino TP 1991. Schistosoma mansoni: influence of infection on levels of translatable mRNA and on polypeptide synthesis in the ovotestis and albumen gland of Biomphalaria glabrata. Exp Parasitol 72: 368-380.

Giovanelli A, Coelho da Silva CLPA, Leal GBE, Baptista DF 2005. Habitat preference of freshwater snails in relation to environmental factors and the presence of the competitor snail Melanoides tuberculatus (Müller, 1774). Mem Inst Oswaldo Cruz, 100: 169-176.

Kawazoe U 1977. Alguns aspectos da biologia de Biomphalaria glabrata (Say, 1818) e Biomphalaria tenagophila (Dorbigny, 1835) (Pulmonata, Planorbidae). II - Fecundidade e fertilidade. Rev Saúde Pública São Paulo 11: 47-64.

King CH, Sturrock RF, Kariuki HC, Hamburger J 2006. Transmission control for schistosomiasis - Why it matters now? Trends Parasitol 22: 575-582.

Livingstone D, Zwaan A 1983. Carbohydrate metabolism of Gastropods. In PW Hochachka, The Mollusca: Metabolic Biochemistry and Molecular Biomechanics, Academic Press. London, Vol. 1, p. 177- 242.

Looker DL, Etges FJ 1979. Effect of Schistosoma mansoni infection on fecundity and perivitelline fluid composition in Biomphalaria glabrata. J Parasitol 65: 880-885.

Magalhães LA, De Lucca O 1971. Determinação do período de desenvolvimento e da viabilidade das desovas de duas populações de Biomphalaria glabrata e Biomphalaria tenagophila (Mollusca, planorbidae). Rev Soc Bras Med Trop 5: 307-313.

Mantawy MM 2001. Potential effect of Allium cepa and Allium sativum on hemolymph of Biomphalaria alexandrina, the intermediate host of Schistosoma mansoni. J Egypt Soc Parasitol 32: 271-283.

Mello-Silva CC 2005. Controle Alternativo e Alterações Fisiológicas em Biomphalaria glabrata (Say, 1818), Hospedeiro Intermediário de Schistosoma mansoni Sambom, 1907 pela Ação do Látex de Euphorbia splendens var. hislopii N.E.B (Euphorbiaceae), PhD Thesis, Universidade Federal Rural do Rio de Janeiro, Seropédica, 85 pp.
Mello-Silva CC, Vasconcellos MC, Pinheiro J, Rodrigues MLA 2006. Physiological changes in Biomphalaria glabrata Say, 1818 (Pulmonata: Planorbidae) caused by sub-lethal concentrations of the latex of Euphorbia splendens var. hislopii N.E.B (Euphorbiaceae). Mem Inst Oswaldo Cruz 101: 1-6.

Minchella DJ 1985 . Host life-history variation in response to parasitism. Parasitology 90: 205-216.

Mott KE 1987. Plant Molluscicides, UNDP/World Bank/WHO, John Wiley \& Sons, New York, 326 pp.

Pimentel-Souza F Barbosa NDC, Resende DF 1990. Effect of temperature on the reproduction of the snail Biomphalaria glabrata. Braz J Med Biol Res 23: 441-449.

Schall VT, Vasconcellos MC, Rocha RS, Souza CP, Mendes NM 2001. The control of the schistosome-transmitting snail Biomphalaria glabrata by the plant molluscicide Euphorbia splendens var. hislopii (syn milli Des. Moul): a longitudinal field study in an endemic area in Brazil. Acta Trop 79: 165-170.

Schall VT, Vasconcellos MC, Souza CP, Baptista DF 1998. The molluscicidal activity of Crown of Christ (Euphorbia splendens var. hislopii) latex on snails acting as intermediate hosts of Schistosoma mansoni and Schistosoma haematobium. Am J Trop Med Hyg 58: 7-10.

Schall VT, Vasconcellos MC, Villaça-Coelho Al, Ferreira-Lopes FE, Silva IP 1992. Evaluation of temporal, seasonal and geographic stability of the molluscicidal property of Euphorbia splendens látex. Rev Inst Med Trop São Paulo 34: 183-191.

Souza CP, Mendes NM, Jannotti-Passos LK, Pereira JP 1992. Uso da casca da castanha do caju, Anacardium occidentale, como moluscicida alternativo. Rev Inst Med Trop São Paulo 34: 459-466.

Sullivan ST, Cheng TC, Houland KH 1985. Studies on parasitec castration of Ilyanassa obsoleta (Mollusca, Gastropoda) by several marine trematodes. Trans Am Microsc Soc 104: 154-171.

Tanatawy AA 2002. Effect of sub lethal concentrations of Atriplex halimus (Chenopediaceae) on Biomphalaria Alexandrina, the snail-vector of Schistosoma mansoni in Egypt. J Egypt Soc Parasitol 32: 297-305.

Thompsom SN, Lee RKW 1986. Comparison of starvation and infection by Schistosoma mansoni on tissue viability and the 31P NMR spectrum of Biomphalaria glabrata. Z Parasitenkd 72: 417- 421.

Vasconcellos MC, Amorim A 2003a. Molluscicidal action of the latex of Euphorbia splendens var. hislopii N.E.B ("Christ's Crown") (Euphorbiaceae) against Lymanea columella (Say, 1817) (Pulmonata: Lymnaeidae), intermediate host of Fasciola hepatica Linnaeus, 1758 (Trematode: Fasciolidae). 1 Test in laboratory. Mem Inst Oswaldo Cruz 98: 557-563.

Vasconcellos MC, Amorim A 2003b. Activity of Euphorbia splendens var. hislopii N.E.B. (Euphorbiaceae) latex against Lymanaea columella (Say, 1817) (Pulmonata: Lymnaeidae), intermediate host of Fasciola hepatica, Linnaeus, 1758 (Trematoda: Fasciolidae). 2. Limited field- testing. Mem Inst Oswaldo Cruz 98: 981-985.

WHO-World Health Organization 1983. Report of a scientific Working Group on Plant Molluscicide and Guidelines for Evaluation of Plant Molluscicide, TDR/SCH-SWE (4)/83.3, Geneva. 